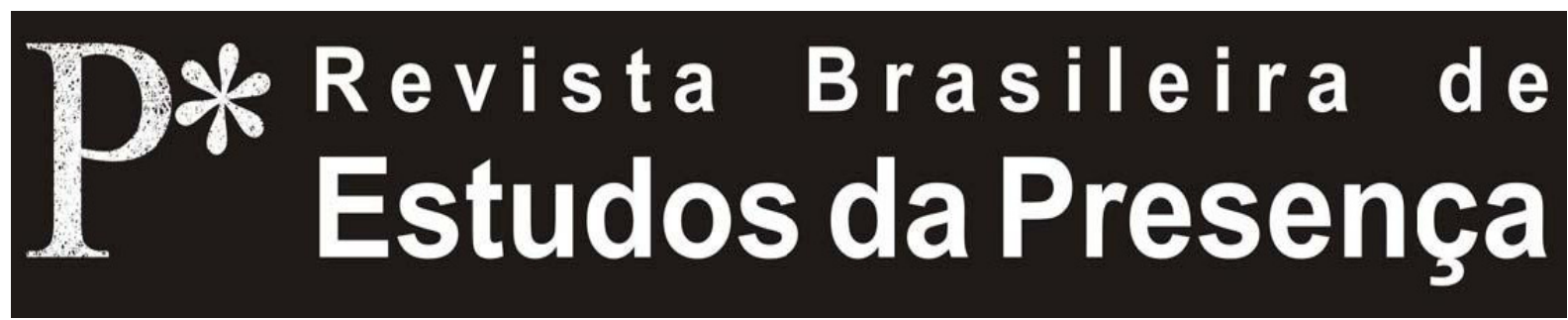

DOI - http://dx.doi.org/10.1590/2237-266026168

ISSN 2237-2660

\title{
Marcas da Violência: vozes insurgentes no Teatro Negro Brasileiro
}

Marcos Antônio Alexandre Universidade Federal de Minas Gerais - UFMG, Belo Horizonte, MG, Brasil

RESUMO - Marcas da Violência: vozes insurgentes no Teatro Negro Brasileiro - Os estudos da etnocenologia retratam os aspectos relacionados com a teatralidade e espetacularidade tanto no campo dos rituais quanto cênicos. Neste sentido, o teatro é um dos suportes para os campos das pesquisas etnocenológicas, sendo o Teatro Negro o foco deste trabalho. Entre as formas de representação do negro na sociedade brasileira, a violência é uma das marcas simbólicas que vêm sendo ressignificada em textos afro-brasileiros. Este ensaio objetiva retratar alguns ecos da violência em textos dramáticos/espetaculares do Teatro Negro Brasileiro. Interessa-me discutir as instâncias em que a violência é representada cenicamente e como ela interfere na (re)construção das identidades e dos sujeitos negros.

Palavras-chave: Etnocenologia. Identidade. Representação. Teatro Negro. Violência.

ABSTRACT - The Taint of Violence: insurgent voices in Brazilian Black Theatre - Ethnology studies report issues related to theatricality and spectacularity both in the scenic and ritual fields. Thus, theatre is one of the supports in ethnoscenological research, and this work focuses on Black Theater. Among the forms of representation of Blacks in Brazilian society, violence is one of the symbolic traits that has been re-signified in Afro-Brazilian texts. This essay aims at portraying some echoes of violence in dramatic/spectacular texts in Brazilian Black Theatre. We intend to discuss the instances in which violence is scenically represented and how this interferes with the (re)construction of black identities and subjectivities.

Keywords: Ethnoscenology. Identity. Representation. Black Theater. Violence.

RÉSUMÉ - Marques de la Violence: des voix insurgées dans le Théâtre Noir Brésilien Les études en ethnoscénologie décrivent les aspects ayant trait à la théâtralité et à la dimension spectaculaire aussi bien dans le domaine des rituels que sur scène. Le théâtre est ainsi l'un des supports pour les recherches ethnoscénologiques et le théâtre noir, plus particulièrement, constitue l'objet du présent travail. Parmi les formes de représentation des noirs dans la société brésilienne, la violence est l'une des marques symboliques qui ne cesse d'être ré-signifiée dans les textes afro-brésiliens. L'objectif de cet essai est donc de transmettre certains échos de la violence dans les textes dramatiques/spectaculaires du théâtre noir brésilien. Il s'agit de réfléchir sur les situations dans lesquelles la violence est représentée scéniquement et sur la manière dont elle interfère dans la (re)construction des identités et des individus noirs. Mots-clés: Ethnoscénologie. Identité. Représentation. Théâtre Noir. Violence. 
O corpo é um portal que, simultaneamente, inscreve e interpreta, significa

e é significado, sendo projetado como continente e conteúdo, local,

ambiente e veículo da memória (Martins, 2002, p. 89).

Armindo Bião (2007, p. 21-41) nomeia algumas noções de referências para as pesquisas no campo da etnocenologia, ressaltando quatro aspectos temáticos importantes - a saber, "Alteridade, identidade[s], identificações, pluralidade e reflexividade"; "teatralidade e espetacularidade"; "estados de corpo e estados de consciência" e "transculturação e estados de consciência" - e que se constituem como parte integrante dos estudos afro-brasileiros, entre os quais eu aqui destaco o Teatro Negro ${ }^{2}$. Cada elemento destacado por Bião aparece, de acordo com as distintas instâncias de enunciação e/ou posicionamento ideológicos e sociopolíticos, na produção teatral em que os negros são retratados cenicamente, reverberando discursos múltiplos e ressonâncias que colocam em destaque reminiscências da cultura afrodescendente.

Partindo do campo dos estudos da crítica literária e enfocando, mais especificamente, o universo de enunciação relacionado ao negro, suas identidades e cultura, bem como sua relação com as artes performáticas, Leda Maria Martins (2002, p. 73) argumenta que "A cultura negra é lugar da encruzilhada". A autora, complementando a sua argumentação, enfatiza que:

Da esfera do rito, e, portanto, da performance, a encruzilhada é lugar radial de centramento e descentramento, interseções e desvios, texto e traduções, confluências e alterações, influências e divergências, fusões e rupturas, multiplicidade e convergência, unidade e pluralidade, origem e disseminação. Operadora de linguagens e de discursos, a encruzilhada, como um lugar terceiro, é geratriz de produção sígnica diversificada e, portanto, de sentidos plurais (2002, p. 73).

Esta encruzilhada a que se refere Martins se converte em um aspecto chave para a minha leitura relacionada ao Teatro Negro Brasileiro, principalmente, quando levamos em consideração os seus "sentidos plurais". Lembremos ainda que 
a "encruzilhada" é lugar de passagem, espaço de encontro e desencontro, terreno de enunciação de Exu, o grande mediador, aquele que é "o porta-voz dos Orixás". Segundo Nei Lopes (2004, p. 266-267),

Na África e na Diáspora, independentemente do orixá a que pertença, todo fiel sempre invoca Exu para que ele não lhe cause problemas. [e Exu] No Haiti, é genericamente conhecido como Legbá e Legbá Petró, Maitre Carrefour [dono da encruzilhada], [...].

As questões relacionadas ao negro, de certa forma, podem ser lidas como representações de encruzilhadas que são ressignificadas nos textos dramáticos e espetaculares ideologicamente, fisicamente, politicamente e socialmente, sobretudo quando observamos os questionamentos que buscam repensar os estereótipos aos quais negros são submetidos nas descrições e enunciações literárias.

Em 1961, Abdias Nascimento já nos trazia algumas inquietações relacionadas ao drama e à dramaturgia negra:

Se há drama negro, sua intensidade dramática será um
resultado de cor, da raça, do seu itinerário histórico? Por
que, diferentemente do drama ocidental (branco), a dra-
mática africana (negro) secundariza o autor para fixar
sua importância no sucesso trágico? Quais relações de
interdependência que guarda esta dramática com a re-
ligião, os ritos, a mitologia, a sociologia? Ou, como as-
severa Roger Bastide, será que o teatro, religiosamente
originado, 'surge apenas quando a fé diminui, permitin-
do ao homem representar o mistério divino em vez de
vivê-lo?' (Nascimento, 1979, p. 19, grifo do autor).

Os questionamentos de Nascimento ainda ressonam na nossa contemporaneidade quando analisamos vários textos teatrais em que os negros são retratados. A título de exemplo, posso citar a montagem mineira de $O$ bom crioulo, uma adaptação da obra de Adolfo Caminha (1895), dirigida por Joselma Luchini, em 2009, e ainda apresentada no circuito teatral belo-horizontino. Apesar de a personagem Amaro ser interpretada por um ator negro, a peça peca por assumir uma leitura em que se exalta mais o corpo negro do que os outros 
possíveis conflitos e questionamentos inerentes ao texto, tais como: o que representaria a história de desejo, paixão, possessão e tragédia no contexto de finais do século XIX? Quais ecos da violência são representados no texto e que podem ser concretizados para o nosso momento de enunciação? Em cena, excetuando a boa representação da atriz que vive a personagem Dona Carolina, amiga e rival de Amaro, o que se vê é a utilização excessiva de estereótipos que alimentam a ideia do negro como objeto sexual, bem dotado e sem cultura. Entretanto, há que se destacar que a peça caiu no gosto do público homossexual, onde a grande maioria comparecia ao teatro para ver os atores que representavam os protagonistas, Amaro e Aleixo, nus.

O Teatro Negro ainda é pouco estudado no âmbito nacional. Por questões distintas - mercado editorial, divulgação, formação de público leitor etc. - e outros fatores alheios ao nosso entendimento, é de conhecimento de muitos que, ainda, há poucas publicações de peças que apresentam a temática negra, e se sabe que o escasso material existente tem circulação restrita a espaços específicos. No entanto, apesar dessa realidade eminente, devo destacar que há autores e grupos que se dedicam a pesquisas e divulgação da cultura afrobrasileira. Para ratificar o meu discurso, entre outros, posso citar a dramaturgia do autor paulista, Allan da Rosa, bem como os trabalhos do grupo carioca, Cia dos Comuns; dos baianos, Bando Teatro Olodum e Cia Teatro Nata; dos grupos mineiros Teatro Negro e Atitude e Cia SeráQuê?; do coletivo brasiliense Grupo de Teatro Cabeça Feita, da atriz, poeta, narradora e dramaturga, Cristiane Sobral, professora de teatro da UNB e primeira atriz negra a formar-se nesta Instituição.

Para esta análise, trago para discussão três obras dramáticas/espetaculares em que os sujeitos negros são o tema central dos conflitos: Cabaré da Rrrrraça, Candaces - A reconstrução do fogo e Da Cabula. São trabalhos em que as representações dos afro-brasileiros podem ser lidas como vozes insurgentes dentro de um sistema social segregador que, muitas vezes, procuram invisibilizá-los. Discute-se a presença de uma violência simbólica que se manifesta, muitas vezes, 
no nível do corpo social, no sentido de Foucault (2003), por meio da exploração dos gestos, atitudes, comportamentos e discursos que são corporificados na dramaturgia ou em cena.

Cabaré da Rrrrraça, peça dirigida por Márcio Meirelles e escrita em colaboração com os atores da companhia, é um dos marcos da produção dramatúrgica e espetacular do Bando de Teatro Olodum e do Teatro Negro Brasileiro. Estreada em 1997, reencenada em 2005, a montagem continua sendo apresentada todos os anos desde então. Trata-se da décima terceira montagem do grupo, cuja temática central é as representações do negro em nossa contemporaneidade. Dentre as formas de representações, a violência física e a simbólica se constituem como marcos da dramaturgia do Bando.

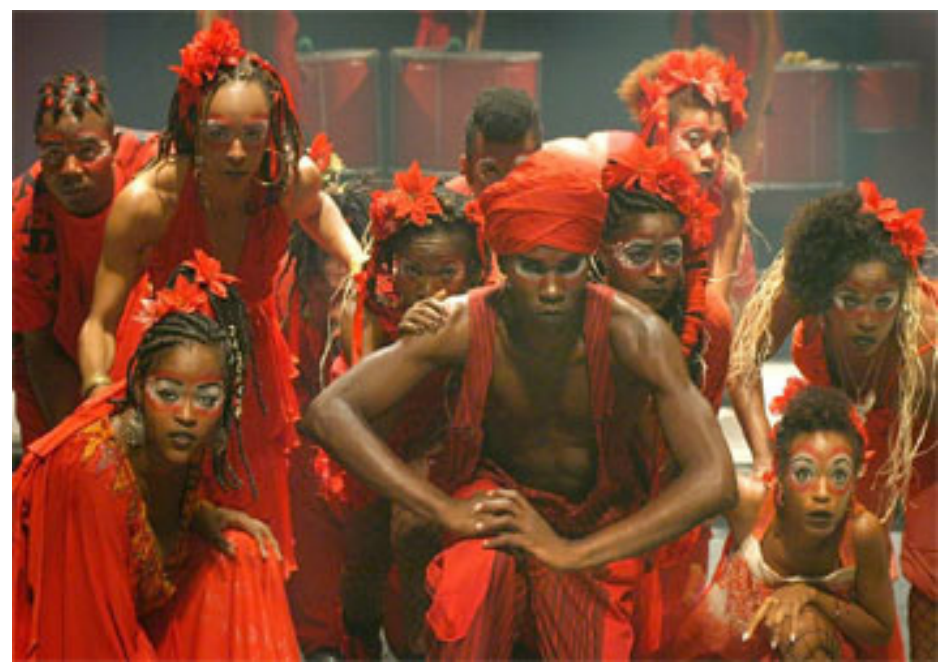

Fotografia 1. Elenco de Cabaré da Rrrrraça ${ }^{3}$

A crítica teatral contemporânea tende a taxar sob o rótulo de panfletários a grande maioria dos textos criados pelas Companhias que produzem Teatro Negro e os textos do Bando Teatro Olodum não escapam a esse olhar analítico. Porém, vejo no adjetivo aqui retratado, em princípio negativo, uma qualidade, à medida que alguns coletivos assumem o panfletário como uma ferramenta metodológica e estética de construção do texto espetacular. Um exemplo bem sucedido disso aparece no texto inicial de Cabaré da Rrrrraça, proferido pela personagem Wensley: 
Boa noite, resistência. Boa noite, brancos. Este é um espetáculo didático, panfletário e interativo. Portanto. Meu nome é Wensley de Jesus. Sou negro e estou fora! Faço questão de dizer isso. Não concordo com esse sistema estruturado por brancos há séculos para nos colocar em padrões que interessam a eles. Por isso, estou fora! Porque para mim ser negro é isso, é estar fora, cavando, buscando evoluir. E a questão que se coloca é: você é negro? Mas, antes disso, o que é ser negro? É essa a discussão que queremos levantar aqui, no Cabaré da Rrrrraça! Canta

CABARÉ DA RAÇA

(Refrão)

Cabaré da Raça

Cabaré é da Raça

Cabaré da Raça

Cabaré, é, é, da raça

Eu quero ver a raça ser passada em revista

Pousando em posição de sentido obrigatório

Ou então quem sabe seja a raça entrevista

$\mathrm{Na}$ contracapa do auditório do

Refrão

(Bando; Meirelles, 1997/2005, p. 2-3)

Com base na citação, é notório que o grupo assume o suposto didatismo e panfletarismo como características. No entanto, isso deve ser lido como uma ferramenta estética utilizada para o grupo trazer à tona os questionamentos sociopolíticos que busca fazer emergir por meio dos discursos retratados em cena pelos atores/personagens ${ }^{4}$.

Desta forma, a partir deste viés, a montagem traz para discussão o negro e as diversas situações que ele enfrenta no seu dia a dia, proporcionando ao leitor/espectador um retrato de negros brasileiros, mais especificamente de baianos, apesar de que podemos estender este panorama para outras cidades do território nacional. Tipologias de negros são trazidas para serem discutidas nas cenas: o negro, o negro alienado, o engajado, o vendido, o revoltado, o universitário, o rico que não se reconhece como negro pela sua posição social, o bom de cama etc.

Para corroborar o assinalado, trago algumas dessas tipologias para discussão como a do negro e a do negro fodido: 
Se o negro é bom de cama? Claro que é! Os dois. Tanto o negro quanto o negro fodido, vou explicar. O negro está no seu escritório, digitando no seu computador, passando seu fax, na teleconferência... aí chega em casa, toma um banho de ducha. Olha a referência: de ducha. Deita na cama redonda com espelho no teto. Aí ó... Tá descansado... Agora, o negro fodido: levantando muro, virando massa, batendo laje e olhe que bater laje cansa, que eu sei que cansa chega em casa, toma um banho de cuia. Olha a referência: de cuia. Vai pro quarto com a nega, deita e dorme. É ou não é bom de cama? E é nessa categoria que eu tô classificado (Bando; Meirelles, $1997 / 2005$, p. 14)

É interessante observar que a violência aqui é simbólica como pode ser observado na fala da personagem anteriormente descrita, Abará. A função bom de cama é questionada, ultrapassando o âmbito físico-corporal para atingir o social. Assim, a estratégia de reflexão do Bando Teatro Olodum é fazer com que a personagem brinque com o estereótipo do negro bom de cama para discutir um dos lugares de representação de grande parte de negros brasileiros, aqueles que vivem em condições econômicas desfavoráveis, que são submetidos a empregos que não os valorizam, patrões que pagam salários ínfimos. O codinome fodido reforça o preconceito e estabelece as diferenças entre os negros socialmente estabelecidos ou não. Fica por conta do leitor/espectador, como em várias outras cenas do texto dramático/espetacular, rever o seu lugar de enunciação.

Devo evidenciar que quaisquer supostos discursos panfletários transcendem as cenas, configurando-se no desenvolvimento da proposta espetacular por meio do enaltecimento do sujeito afrodescendente com a exploração de imagens e nuanças distintas. Em alguns momentos, exalta-se a figura negra como podemos observar na apresentação da personagem Dandara:

Claro que sou negra. Linda. Assumida. E o que é melhor: sem nenhum trauma. Meu nome é Dandara, faço faculdade de interpretação na escola de teatro, mas não pensem que foi fácil chegar lá não. Eu tive que estudar muito. Agora, claro, minha família sempre me deu a maior força; eu sou filha única.

$\mathrm{Eu}$ já fui muito discriminada por aí, sabe? Ouvi mui- 
tas piadinhas sem graça. Dói. Mas eu sempre tirei de letra, estudando e tentando conquistar o meu espaço. Posso dizer uma coisa pra vocês: o negro simplesmente não comanda o mundo porque não sabe a força que tem (Bando; Meirelles, 1997/2005, p. 5).

Seu discurso revela não só o sujeito que se reconhece como negro, mas, principalmente, aquele que tem orgulho de sua etnia e que, mesmo reconhecendo que sofre preconceitos, valoriza a sua raça, sua cultura e tem consciência de sua força e poder.

Em outros trechos do texto observa-se uma crítica direta e/ou indireta em relação à postura ideológica de outras personagens. Esta assertiva pode ser comprovada a partir da leitura das falas de uma cantora que se diz morena, Karine:

Essa questão de etnia pra mim não tem importância: se é preto, branco, amarelo... Na minha casa todo mundo é branco, eu sou morena. Mas acho que eu tenho algum antepassado negro, porque eu gosto dos negros, eu tenho o suingue dos negros (Bando; Meirelles, 1997/2005, p. 3-4).

Diferentemente da personagem Dandara, Karine pode ser interpretada como um sujeito alienado, aquele que exalta a sua ascendência, mas não se considera negro.

Outra personagem que também apresenta um discurso negativista é Rose Marie, uma mulher de posses que não se sente negra pelo fato de sua condição econômica:

Entra, descendo as escadas. Desfila até o palco, seguida e cortejada pelos homens. Negra, eu? Eu nasci bem, sou de boa família, nunca tive problemas financeiros, tenho minha empresa, o gerente do banco onde tenho conta me dá tratamento vip. Não entendo isso que vocês estão discutindo aqui: questão de raça, de cor?... Eu, Rosie Marie, nunca fui discriminada.

Homens tocam percussão (Bando; Meirelles, 1997/2005, p. 4).

A postura elitista da personagem é reforçada cenicamente por meio das ações físicas da personagem/atriz, que muda a sua voz, impondo um tom de falsete, seus gestos vão do empinar 
o nariz para demonstrar a sua altivez até o meneio do corpo ao mover as cadeiras com elegância num ritmo provocativo e sedutor.

Por outro lado, é interessante ressaltar que o discurso elitista e segregador de Rose Marie é desconstruído cenicamente, pois ela se transforma assim que escuta o som dos tambores. Seus gestos corporais são ressignificados, fazendo com que a personagem, brechtiniamente, dê voz ao discurso questionador da atriz Rejane Maia. O distanciamento permite que o limiar atriz/personagem se dilua na cena e nas ações físicas e dramáticas propostas pelo texto dramático/espetacular:

\begin{abstract}
ROSE MARIE:
Dança como se tivesse encarnado uma entidade, transforma-se. Fala a atriz. Agora eu, Rejane Maia, atriz... sou discriminada desde a hora em que acordo, e vejo a condição de vida das pessoas que moram na comunidade em que vivo, Ogunjá/Boa Vista de Brotas ${ }^{6}$. Sou discriminada quando pego o ônibus e criticam minha roupa, meu cabelo. Sou discriminada quando vou ao supermercado e o fiscal me segue como se eu estivesse roubando. Eu paro e digo: "Qual é, meu irmão? Perdeu alguma coisa?" Sou discriminada porque sou mulher e porque sou negra e muitos acham que eu devia estar pilotando o fogão da cozinha de alguém ou usando minha força para limpar a sujeira de suas casas ou de sua cidade; que o leite farto de meu peito devia estar alimentando os filhos dos outros; que minha bunda firme e dura devia estar nos motéis da vida. Mas sou mulher e sou negra e minha força vai ser usada para honrar a memória de meus antepassados: reis, guerreiros e sacerdotes que foram arrancados de suas terras para trazerem para esse novo mundo seu trabalho, suas lágrimas e sua alegria. Sou mulher e sou negra e meu leite vai para os filhos que saírem do meu ventre ou para aqueles que eu resolva adotar. E meu corpo vai para o homem que eu escolher e souber me amar e me respeitar. E minhas ancas são para requebrar na batida guerreira de minha raça. Minha mãe não é Nossa Senhora, é Nanã Boroquê.
\end{abstract}

TODOS:

Enquanto Rose Marie samba

Nega do balaio grande,

olha o balaio,

Nega do balaio grande,

olha o balaio ${ }^{7}$

(Bando; Meirelles, 1997/2005, p. 4-5). 
A fala anuncia, enuncia e legitima o lugar de enunciação discursivo e ideológico não só da atriz/personagem, mas também se converte em um macrossigno representando a voz de milhares de mulheres negras baianas e/ou brasileiras; sujeitos que muitas vezes ainda se veem submetidos a visões estereotipadas e preconceituosas tais como: a boa de cama (alusão distorcida de que toda negra(o) tem um desempenho sexual extraordinário); a mulher de forno e fogão (aquela que tem os dons culinários e é vista como a empregada que cuida da casa, da cozinha e que se viu obrigada muitas vezes a servir na mesa - a família - e, na cama -, o patrão) e a boa de leite (a babá que está pronta para criar o fillho do senhor - visão antiquada advinda do regime escravocrata - a mãe preta). Positivamente, o discurso aqui apresentado vai de encontro às ações da personagem Rose Marie, visto que, a partir da voz e das ações perlocutórias, a atriz/personagem é reconfigurada reconhecendo-se como discriminada; mas, ao mesmo tempo, ela reivindica o seu espaço, a sua etnia, a sua cultura e demonstra que reconhece o seu valor como mulher negra.

A cultura negra, representada por meio da religião, também é valorizada na fala de Rejane Maia quando finalmente ela enuncia que "Minha mãe não é Nossa Senhora, é Nanã Boroquê". O mais importante não é o fato de a atriz/personagem negar Nossa Senhora - uma das representações máximas do cristianismo -, mas, sim, a evocação e o reconhecimento de Nanã Buruku ${ }^{8}$ como orixá de cabeça. Na verdade, reforçando a minha argumentação, não se trata de simplesmente negar o catolicismo ou, muito menos, de menosprezar a importância dos cultos a Nossa Senhora que são praticados em todo território brasileiro; mas, sim, valorizar e dar voz e representatividade à religião afrodescendente. A partir de seus estudos sobre os Orixás, Pierre Verger esclarece que "Nanã Buruku é conhecida no Novo Mundo, tanto no Brasil como em Cuba, como mãe de Obaluaê-Xapanã. É sincretizada com Sant'Ana no Brasil e com Nossa Senhora do Carmo ou Santa Teresa em Cuba" (1997, p. 240). Ou seja, de certa forma, há uma dupla relação existente entre Sant'Ana (a mãe da Virgem Maria)/ Nanã Buruku que se reconfigura sincreticamente, entretanto, no texto dramático/espetacular, se preserva a matriz africana. 
O estudo das matrizes religiosas e de seus respectivos rituais é um elemento caro às pesquisas em etnocenologia, que, por sua vez, integra a grande maioria dos textos que tratam da temática negra. A religião na peça é pano de fundo para discussões maiores, revelando preconceitos arraigados às sociedades contemporâneas acerca dos cultos considerados profanos, que, muitas vezes, são acusados de bruxaria, coisas do demônio etc. Ao valorizar a matriz africana, os atores do Bando ressignificam a importância de se manter a cultura religiosa dos negros e de seus ancestrais.

A música é outro elemento estético recorrente nos textos dramáticos do Bando Teatro Olodum e, por sua vez, muito utilizado em suas montagens. Em Cabaré da Rrrrraça não é diferente. O recurso musical é introduzido logo no início do espetáculo quando todos os atores-personagens cantam a música tema da peça Cabaré da Rrrrraça. O som dos tambores, dos instrumentos de percussão e as ações coreográficas não só dão cadência ao texto espetacular como também reforçam o caráter ritualístico e de espetacularidade presente no texto dramático e concretizado na montagem. Lembremos que teatralidade e espetacularidade são aspectos fundamentais para os estudos dentro do campo da etnocenologia e tais características, sem dúvida, são muito relevantes para a leitura de texto dramático/ espetacular: rito e performance emergem dos corpos mnemônicos dos atores, que evocam a relação ancestral da negritude, permitindo o constante diálogo entre passado e presente. As músicas e ritmos propostos pelo Bando vão do samba popular, dos ritmos contemporâneos do pagode e do axé baianos até o rap. Vejamos o Rap do 13 de maio:

\footnotetext{
O poder tem uma dança interessante Quando resolve te tirar como otário. Dá uma pirueta, inventa datas importantes Alguma coisa que só tem no calendário

O dias do Isso, o Dia do Aquilo...

No dia a dia é Dia de coisa nenhuma

Não sei se pulo de alegria e comemoro

Ou se ponho os pés no chão, penso e choro

Cadê o país da independência, cadê?
} 
Cadê o país da abolição, cadê?

Tudo que eu vejo é um sistema em decadência

Há muito tempo reciclando a escravidão

"Eu me vali desse discurso panfletário, Mas à minha burrice faz aniversário Ao permitir que num país como o Brasil" A liberdade seja só um fato imaginário.

Queima de estoque da história da nação Velhas verdades foram postas no balaio As nossas vidas estão em liquidação No mercado negro, dia treze de maio. (Bando; Meirelles, 1997/2005, p. 16-17).

Anízio Vianna argumenta que:

No rapper verificamos o desejo de ir além do artista e dar um grau de coerência aos fragmentos que compõem a sua história pessoal e comunitária para que, assim, o sujeito possa emergir de um contexto social dado e redefini-lo 'para o presente' (Viana, 2007, p. 143).

Aproprio-me dos dizeres de Vianna por considerar que tanto o texto dramático quanto o espetacular do Bando cumprem com a função de recontextualização dos fatos e situações enfrentados pelo negro nas sociedades contemporâneas. Neste sentido, sem sombra de dúvida, a música é um dos elementos que propicia a sua de reintegração social que se reconcretiza por meio do rito espetacular. No Rap do 13 de maio, a batida do instrumento e o gesto corpóreo dos atores em cena é desconstruído pelo discurso irônico proposto pela letra: "Cadê o país da independência, cadê?/Cadê o país da abolição, cadê?" Produz-se um momento de ruptura e em cena surge um corpo social que discute as instâncias de legitimação do 13 de maio, enquanto lei e suas representações simbólicas através dos tempos na escola, no trabalho, nas distintas esferas sociais em que o negro ainda se vê segregado.

Diante do expresso, vale a pena destacar que, no momento de corporivivência dos rituais cênicos aqui discutidos -o (re) encontro com Nanã e o corpo-memória trazido pelo rap-, a dimensão espacial, corporal e memorialística é rompida dando a possibilidade de que se presencie uma nova integração. 
Há um ato de inscrição corporal, de religare, conjugando no mesmo plano corpo, chão (terra/pó), gestus ${ }^{9}$, voz, palavras, uma nova forma de habitar os espaços físicos, concretos e mnemônicos. O ato de habitar (Ricœur, 2000, p. 191) é estabelecido por meio da (re)construção de uma tessitura textual e corpórea em cena e, com ele, podemos vivenciar uma escritura que é performática e litúrgica no tempo e no espaço, inscrevendo assim a oralitura $^{10}$, dando forma a uma tessitura de memória pessoal e coletiva de uma diáspora da cultura negra que se converte em um repertório que enuncia um discurso de integração corporal, social e comunitária.

Outra peça que trago para discussão é Candaces: a reconstrução do fogo (2003/2004), do grupo carioca Companhia dos Comuns ${ }^{11}$, também com encenação, direção e dramaturgia de Marcio Meirelles. O texto espetacular é concebido a partir da reinvenção artístico-histórica das Candaces. É construído um mosaico de histórias protagonizadas por personagens femininas comuns, demonstrando um retrato da mulher negra brasileira que enfrenta com determinação distintos tipos de violências físicas e simbólicas.

\author{
VOZES DE CHICA XAVIER, LÉA GARCÍA, \\ RUTH DE SOUXA E ZEZÉ MOTA - \\ O tempo é o Senhor das histórias. \\ O tempo guarda muitas histórias \\ para sempre. \\ As histórias ficam guardadas para \\ sempre no reino do Tempo, \\ quando não são contadas. \\ As histórias não são contadas quando \\ não existe voz que as conte, \\ quando as vozes não são ouvidas, \\ quando as vozes são caladas, \\ quando ouvidos não conseguem \\ escutá-las, \\ quando ouvidos não entendem o que \\ escutam. \\ Temos muitas histórias para contar. \\ Temos então que restaurar nossa voz. \\ Temos que acostumar os ouvidos ao \\ som dessa voz restaurada. \\ Temos que tirar as histórias do reino \\ do Tempo (COMPANHIA, 2003, p. 1).
}


Com este texto que evoca a função griot, neste caso, por meio de vozes femininas que irrompem o silêncio e vivificam na memória corporal, pessoal e coletiva do leitor espectador, abre-se a montagem ${ }^{12}$. É como se fosse uma evocação ao tempo espiralar (Martins, 2002), que pode ser lido como um chamado para que o leitor/espectador possa abrir os sentidos (escutar, ver, antever) para os fatos que serão reconcretizados na peça. Em outras palavras, o tempo - o guardião das histórias - evoca tessituras verbais e vocais que serão trazidas para discussão no desenlace dos conflitos dramáticos.

Shanakdakete, Amanirenas, Amamishakete, Amamitere eram as Candaces, rainhas e guerreiras negras que viveram antes da Era Cristã, detendo o poder no Império Méroe. Com estratégia e força, enfrentaram o Império Romano, comandando seus exércitos. Com base na concretização intercultural destas personagens, a Cia. dos Comuns adentra no universo feminino afrodescendente e destaca os percalços e os avanços, bem como a riqueza que se manifesta no campo da palavra que é ressignificada em atos mnemônicos, do rito performático rememorado a partir das referências ao candomblé, das canções e sonoridades que têm como base a matriz africana. Elementos que marcam a trajetória das mulheres negras e as contribuições políticas, culturais e sociais delas são destacados.

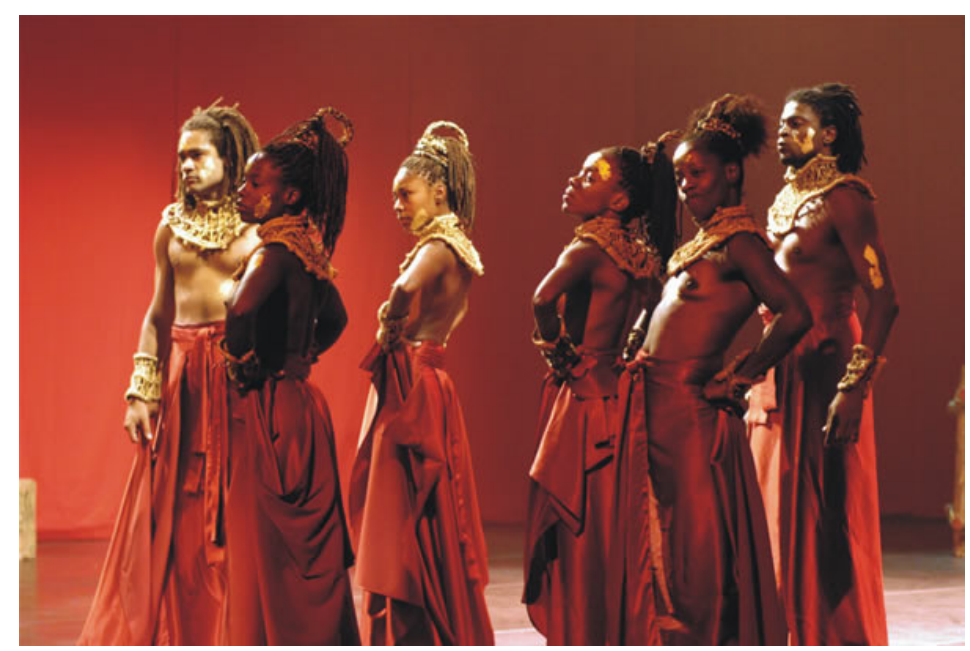

Fotografia 2. Elenco de Candaces $^{13}$

O texto dramático é construído a partir das experiências pessoais de cada integrante do elenco e também de impor- 
tantes depoimentos/testemunhos compilados de entrevistas realizadas com 28 mulheres negras de diferentes classes e representações sociais - poderíamos dizer, mulheres/Candaces de nossos tempos -, entre outras: Aglaete, Alzira Fidalgo, Chica Xavier, D. Ivone Lara, D. Zica, Daí, Helena Theodoro, Jurema Batista, Léa Garcia, Lúcia Xavier, Mãe Edelzuta, Ruth de Souza, Tia Doca, Tia Neném, Tia Surica, Vanda Ferreira, Veluma, Vera do Agbara, Zezé Motta.

Nesses depoimentos/testemunhos, as palavras, em seu conjunto, expressam muito mais que sintagmas, mais uma vez, elas irrompem o silêncio, denunciam, posicionam-se: “[...] Então aprendi, sou negra, sim. E politicamente, não é a cor da pele que o negro é - é esse ser ancestral que nós somos" (Veluma apud COMPANHIA, 2003); "Ser mulher negra é complicado, porque ela ganha menos que a mulher branca e menos que o homem negro. A mulher tem que administrar o salário mínimo na grande miséria, é a provedora da casa" (Motta apud COMPANHIA, 2003) e, entre outras falas, chamame atenção as palavras de Ruth de Souza, uma das grandes damas e ícones do teatro negro brasileiro:

\begin{abstract}
Nunca havia feito teatro. Minha mãe, como gostava muito de opereta, me levava para assistir a algumas. Passei a apreciar com outros olhos e hoje sou atriz e gosto de ser. Mas sempre soube que seria muito difícil alcançar, por exemplo, um papel principal, por ser negra. Porque ser mulher e negra é ter que lutar duas vezes pelos seus ideais (Souza apud COMPANHIA, 2003).
\end{abstract}

Na dramaturgia de Candaces são trazidas para cena vozes de mulheres que integram as comunidades de baixa renda. São mulheres marcadas pela violência corporal, psicológica e social. Dentre estas mulheres, recupero as palavras-escrevivências ${ }^{14}$ da personagem Neia:

Ô, moço ajuda. Meu filho tá caído assim e sujo, mas ele não é vagabundo não. Ele tá é cansado. A gente tá muito cansado de tudo isso... Ele cansou de procurar emprego. Outro emprego melhor do que o do pai... de pedreiro, porque emprego de pedreiro não é respeitado, não. Trabalha como dá... não conseguiu outro emprego, porque 
não tinha estudo. Mas a gente cansou de procurar estudo pra ele. [...] Calu era mestre de obra e eu lavava... mas o dinheiro não dava pra tudo, não. A gente tinha que cuidar do pai de Calu, que era cego e não tinha previdência. E da irmã de minha mãe que morava com a gente e era fraca do juízo. Aí, o meu menino teve que ajudar o pai. Eu mandei o pai ensinar o ofício. Perdeu interesse pelo estudo. Cansou. Cansou de chegar na porta da escola e voltar porque não tinha aula. O professor faltou ou tava em greve. Cansou de não ter o seu pra comprar suas coisinhas... começou a trabalhar... aí não achou nada melhor, porque não tinha mais estudo. Agora tali, deitado. Parece criança. Levanta meu filho. Pare que tá dormindo... Ele dormia bem. Não deu trabalho esse daí. $\mathrm{E}$ foi o único. O outro, eu mais Calu achou que não ter e não nasceu. $\mathrm{O}$ médico do posto que me atendeu... que o aborto deu complicação... ligou as trompa, que disse que era melhor. Que eu não devia ter mais filho mesmo... Levanta, menino... Quando nasceu, primeiro foi a confusão pra arranjar leito no hospital. Mas ele era brabo e nasceu no corredor mesmo. Quase eu de pé. Eu gritava 'tá nascendo' e não tinha nem enfermeira nem médico pra aparar. Deitei no chão e ele começou a nascer. Foi assim. Agora taí, deitado. Ele tava lá em cima, no andaime... e agora, aí dormindo. Cansou. Levanta, meu filho. Vamo pra casa deitar. Amanhã tu acaba o serviço. Eu falo com teu pai (COMPANHIA, 2003, p. 1).

As diversas formas de violência estão por trás de cada frase proferida pela personagem, denunciando faltas inerentes à vida de muitas mulheres e famílias iguais no infortúnio: falta de estudo dos filhos e más condições educacionais na grande maioria das escolas públicas brasileiras, falta de saúde pública, de escola, de trabalho, de comida, de possibilidades de vida e, acima de tudo, de vida digna etc.

São aspectos múltiplos que vão sendo linkados a partir de um discurso simples e entrecortado. São propostos silêncios que gritam nos ouvidos do leitor-espectador que é chamado a compactuar com a dor da personagem. Uma releitura crítica das letras clássicas de Chico Buarque Meu guri e Construção? Esta última, sem o último beijo da mulher amada e do filho, aqui, não concebido. Como uma obra aberta, pronta para uma leitura transversal ${ }^{15}$, o texto dramático/espetacular propicia outra possível leitura... O guri cresceu, virou homem em meio à violência social, e, contrariando a linha pré-estabelecida 
pelo destino mundano - ou seria pelo oráculo contemporâneo do submundo? -, não virou bicho solto; mas seguiu o destino traçado pelos pais, virou pedreiro. $\mathrm{O}$ diferencial aqui é que ele, como tantos outros brasileiros, morre não a tiro de bala, mas enquanto exercia o seu ofício de pedreiro. "Morreu na contramão atrapalhando o tráfego..." "Olha aí! / Ai o meu guri, olha aí! / Olha aí! / É o meu guri, e ele chega [...]”.

Não posso deixar de evidenciar que o espetáculo ganhou o Prêmio Shell/2003 de Melhor Música, tendo sido indicado em mais três categorias: (Direção, Figurino e Categoria Especial/Coreografia); foi também eleito pelos Jornais $O$ Globo e Jornal do Brasil como um dos 10 melhores espetáculos de 2003. Na leitura da crítica Bárbara Heliodora:

\begin{abstract}
A encenação é uma bela apologia da dignidade da mulher negra, com um texto que mistura a evocação de histórias e mitos das ancestrais africanas e os problemas do cotidiano da comunidade negra, sua luta pela dignidade individual e de grupos em face das barreiras, dos preconceitos ostensivos ou sub-reptícios [...] (Heliodora, 2003, online $)^{16}$.
\end{abstract}

O último texto que apresento nesta discussão é Da cabula, de Allan da Rosa dos Santos. Nascido em Taboão da Serra, em São Paulo, Allan da Rosa é poeta, contista, narrador e dramaturgo ${ }^{17}$. Um dos promissores escritores de sua geração. Dono de uma linguagem contundente e de uma escrita comprometida com as mazelas de uma população que é excluída das benesses de nossas sociedades.

Dentro desta linha, encontra-se o texto dramático $D a$ $\mathrm{Cabula}^{18}$, peça em que o autor assume uma escrita comprometida com a enunciação do sujeito negro e a sua integração na sociedade. Nei Lopes, na apresentação do livro no qual a obra é publicada, explicita que "O texto de Allan da Rosa quer e consegue dinamitar e implodir as torres desta sociedade excludente" (Lopes, 2008, p. 14).

A personagem protagonista da peça é Dona Filomena da Cabula, uma personificação de milhares de mulheres pobres brasileiras. Ela é negra, empregada doméstica, analfabeta e tem o grande sonho de aprender a ler para poder mudar, de al- 
guma maneira, a sua perspectiva de vida. Fora casada, iludida por um sujeito que se dizia empresário em Minas, abandona a Mãe (personagem que se personifica textualmente por meio de sonhos durante o desenvolvimento das ações dramáticas), teve uma filha, que perde pela vida.

Filomena da Cabula é o tipo de personagem complexa e repleta de representações semânticas. É uma representante típica de uma grande parcela de brasileiros excluídos - trabalha o dia inteiro e vai à noite para a escola com o objetivo de aprender a ler e escrever, é motivo de chacota dos patrões pelo fato de estudar, decide largar o emprego, alugar um quartinho e acaba pagando pelo ponto de uma banca de camelô sonhando em mudar de vida:

\begin{abstract}
(Abraça a vassoura. Fecha os olhos de emoção.)
FILOMENA - Ai, que delícia. Pena que não conheço ninguém aqui pra esses canto, pra comemorar comigo. Beijar, abraçar. Me dar os parabéns. Se tivesse cinema, eu ia pra comemorar, mas melhor que nem tem, aí eu nem gasto o dinheiro... E passar carão? De frente pro cartaz e perguntar o nome do filme? Quanto é? Que hora começa? E o bilheteiro apontando com o dedo aquelas tabelas tudo doida, aqueles cartaz que eu não entendo nada. Perguntando se eu não sei ler, não... mas deixa estar... Agora Filomena da Cabula vai viver. Deus me dando saúde [...] (Rosa, 2008, p. 30).
\end{abstract}

No entanto, o sofrimento de Filomena não muda. Apenas aprofunda. Como bem explicita Conceição Evaristo, na orelha do livro, "Filomena da Cabula transitava em espaços delimitados". Agora, ela é dona de seu destino, tem o seu negócio, mas tem que acordar de madrugada para pegar a condução para chegar ao trabalho, de onde sai tarde da noite esgotada e não tem energias para ir à escola para dar continuidade ao seu processo de alfabetização. Em princípio, ela acredita que conseguirá fazer as tarefas em casa, mas quando chega ao seu barraco, mesmo enchendo-se de café, o seu corpo pesa mais que a sua força de vontade e acaba quase sempre dormindo sobre os cadernos. Evaristo ainda argumenta 
Filomena, como muitas pessoas que ainda hoje não dominam a leitura e a escrita, vivia uma cidadania mutila$\mathrm{da}$, inconclusa, em uma sociedade que se organiza a partir de leis, decretos, documentos, papéis, todos grafados, assinados, letras [...]

(Evaristo, 2008, prefácio).

Neste contexto, eclodem alguns questionamentos: em que lugar se insere o discurso desses marginalizados? Que estratégias são de fato eficazes para que as vozes oprimidas possam vir a ser representadas dentro do discurso hegemônico?

Um dos pontos fortes da dramaturgia de Allan da Rosa é a inserção do universo onírico à sua peça. Do esgotamento de Filomena, de seus traços/rasuras de uma tentativa de escrita de si e para si, surge a personagem Flores Vermelhas, que imprime na dramaturgia um acesso a uma representação mnemônica que desvela não só nuances da personagem como também imprime à dramaturgia ecos de vozes que se interconectam com o imaginário do negro e de sua cultura ancestral:

Vendaval: um moleque entre meus joelhos. Surge minha filha, meu genro. Quanto abraço! Pauline luzindo no sol, mirando montanhas, inspirando o ar do litoral. Saudade salga meus cílios. Fazer o quê? Mãe tem que aceitar a trilha da cria... Levo o traquinas pra passear. Ele dá piruetas, vem com chamego pedir moeda pro sorvete. Danado (Rosa, 2008, p. 56).

O sangue riscava minha pele negra, rios rasos de carne, arranhões dos espinhos. Veloz eu ia rompendo emaranhados de arbustos, pisando gramas selvagens, pedregulhos. Meu sangue se mesclando às flores e frutos. Permanecendo eu, me ficando, me deixando no que nasce do tempo verde. Procriando movimento, rasante, devassando o magnífico horizonte, fertilizando a beira das ribanceiras. Me deixando futura no caminho, meu apetite de espaço e de ternura (Rosa, 2008, p. 66).

Eu, Filomena da Cabula, vou preparando um ebó, lavrando com sabores e cantos, de cores, a terra porosa. Prestando reverência. Quanto do mar escoou pó estas raízes? Quanto de suplicio e flagelo na casca dessas árvores? Quanto de balanço banzeiro das ondas no nervo dessa terra? [...] (Rosa, 2008, p. 81). 
Nas palavras de Evaristo, "A personagem imagina e constrói na escrita uma outra história para si e para os seus. Uma memória longínqua, ancestral, permite e induz a sonhos" (2008, prefácio).

Não há como não deixar de observar as marcas semânticas que integram o texto dramático e a proposta estética do autor, de incorporar o sonho - que é corporificado cenicamente - ao seu texto, imprime à peça uma aproximação com o universo da fabulação que integra a cultura afrodescendente em suas distintas formas representacionais em nossa cultura. Em uma possível leitura espetacular, abre-se espaço para distintas possibilidades de concretização do texto dramático. A encruzilhada vivida por Filomena da Cabula e, por sua vez, por todas as personagens coadjuvantes que aparecem ao longo do desenvolvimento das ações dramáticas é mote enunciador do negro agente e mediador de sua própria condição.

A guisa de conclusão, gostaria de reiterar o porquê da escolha dos textos dramáticos/espetaculares aqui discutidos, pois todos são representantes do Teatro Negro Brasileiro, visto que apresentam os afro-brasileiros como sujeitos de enunciação. Além do recorte pelo viés da violência - física, simbólica, identitária, pessoal, coletiva -, finalmente, interessa-me destacar para minha reflexão crítica que, nesses textos, as vozes insurgentes representam um corpo negro pulsante. Conceitualmente, estou entendendo esse corpo negro pulsante como um elemento gestor que produz e, ao mesmo tempo, integra uma matriz ancestral, àquela que traz em si um elo com o continente africano e é uma matriz/corpus de reminiscência de memórias pessoais e coletivas que são evocadas por meio do corpo negro em performance espetacular ou escrita. Retomando os meus argumentos iniciais, ratifico a assertiva de que são nas entrelinhas das encruzilhadas, territórios de Exu, que são gestados e tecidos os conflitos dramatúrgicos que integram o Teatro Negro Brasileiro.

Laroyê Exu! Epa babá, Oxalá! Odoyá, minha mãe! 


\section{Notas}

${ }^{1}$ A descrição e o horizonte teórico-metodológico podem ser consultados em Artes do Corpo e do Espetáculo: questões de etnocenologia, organizado por Armindo Jorge de Carvalho Bião (2007, p. 21-41).

${ }^{2}$ Trata dos textos dramáticos e/ou espetaculares em que os negros, suas identidades e sua visão ideológica do (e para o) mundo aparecem como temática central, ou seja, espera-se que seja apresentado o ponto de vista interno inerente aos negros. Não obstante, em uma perspectiva mais abrangente, o Teatro Negro por excelência não apenas retrata as especificidades dos sujeitos negros e sua integração na sociedade, mas também se nutre dos elementos que compõem e integram a cultura dos afrodescendentes em suas diversas manifestações artístico-performáticas: danças, músicas, jogos, mitos e ritos. Vale destacar que, na minha leitura crítica, leio e entendo o Teatro Negro, considerando ainda que o mesmo deva retratar os contextos e lugares de enunciação aos quais os negros se viram e ainda se veem representados e/ou subjugados em nossas sociedades. Também defendo a ideia de que, esteticamente, esse teatro pode vir a ser praticado por não negros, uma vez que o aspecto mais importante é ter o afrodescendente e a sua cultura como elemento de concepção dramática/espetacular/etnocenológicas.

${ }^{3}$ Foto de Márcio Lima. Disponível em $<$ http://mundoafro.atarde.com.br/?tag=cabare-darrrrraca $>$. Para ver trechos do espetáculo, acesse os seguintes links: $<$ http://www.youtube.com/ watch? $\mathrm{v}=$ KhoocnLEGFE $>$; $<$ http://www.youtube.com/watch? $\mathrm{v}=$ Bovwy_4211M\&feature=rela ted $>$ ou $<$ http://www.youtube.com/watch? $=$ X0tt1Tzbhho\&feature=related $>$.

${ }^{4}$ Uma das características das encenações do Bando Teatro Olodum é vincular o nome dos atores à dramaturgia cênica. Assim, em vários momentos há uma diluição das categorias ator x personagem, as representações assumem características de personas - papel social, máscara social.

${ }^{5}$ Esta e outras cenas que compõem esta análise podem ser vistas, consultando um vídeo com fragmentos do espetáculo, disponível em: $<$ http://www.youtube.com/watch?v=Bovwy_4211 M\&feature $=$ related $>$.

${ }^{6}$ Um bairro popular de Salvador.

${ }^{7}$ Samba popular tradicional.

${ }^{8}$ Segundo Pierre Verger (1997, p. 236), "Nàná Buruku ou Nàná Bùkùú ou ainda Nàná Brukung é uma divindade muito antiga. A área que abrange o seu culto é muito vasta e parece estender-se de leste, além do Níger, pelo menos até a região tapá, a oeste, além do Volta, nas regiões dos guang, ao nordeste dos ashanti". O antropólogo ainda explicita que "Nanã Buruku é o arquétipo das pessoas que agem com calma, benevolente, dignidade e gentileza. Das pessoas lentas no cumprimento de seus trabalhos e que julgam ter a eternidade à sua frente para acabar seus afazeres. Elas gostam das crianças e educam-nas, talvez, com excesso de doçura e mansidão, pois têm tendência a se comportarem com a indulgência dos avós. Agem com segurança e majestade. Suas reações bem-equilibradas e a pertinência de suas decisões mantêm-nas sempre no caminho da sabedoria e da justiça” (Verger, 1997, p. 241). 
${ }^{9}$ Aqui entendido a partir dos dizeres de Patrice Pavis (1999, p. 187 - grifo do autor): "O gestus é sensível, ao mesmo tempo, no comportamento corporal do ator e em seu discurso: um texto, uma música podem, na verdade, ser gestuais se apresentam um ritmo apropriado ao sentido do que ele está falando".

${ }^{10}$ Conceito proposto por Leda Martins (2002, p. 87, grifos da autora): “A esses gestos, a essas inscrições e palimpsestos performáticos, grafados pela voz e pelo corpo, denominei oralitura, matizando na noção deste significante a singular inscrição cultural que, como letra (littera) cliva a enunciação do sujeito e de sua coletividade, sublinhando ainda no termo seu valor de litura, rasura da linguagem, alteração significante, constitutiva da alteridade dos sujeitos, das culturas e de suas representações simbólicas".

${ }^{11}$ Os três primeiros trabalhos integram a trilogia da Cia. dos Comuns: A Roda do Mundo (2001), Candaces - A Reconstrução do fogo (2003) e Bakulo - Os bem lembrados (2005). Esses textos foram escritos pelo encenador e diretor Márcio Meirelles e foram criados a partir de um processo de construção coletiva que partiu das percepções de cada ator na construção das personagens. A quarta montagem do grupo é Silêncio (2007) e esse texto toma status de primeiros passos, uma vez que Hilton Cobra - diretor da Cia dos Comuns - assume, juntamente com a participação coletiva dos integrantes do grupo, a dramaturgia, desta vez, sem contribuições externas. Faço uma breve análise desta peça no trabalho "A cultura negra e seus questionamentos na produção dramatúrgica/espetacular contemporânea", publicado no volume 4 da Antologia Literatura e afrodescendência no Brasil: antologia crítica (História, teoria, polêmica), organizada por Eduardo de Assis Duarte e Maria Nazareth Soares Fonseca (Editora UFMG, 2011).

${ }^{12}$ Para ver um trecho do espetáculo, acesse: $<$ http://www.videolog.tv/video.php?id=252893>.

${ }^{13}$ Disponível em <http://www.comuns.com.br/fotos_candaces/1.jpg $>$.

${ }^{14}$ Aqui faço alusão ao conceito difundido por Conceição Evaristo (2007, p. 20-21, grifos meus). Evaristo, ao discutir sobre a sua escrita, propõe o seguinte questionamento: "O que levaria determinadas mulheres, nascidas e criadas em ambientes não letrados e, quando muito, semialfabetizadas, a romperem com a passividade da leitura e buscarem o movimento da escrita?". Logo, a autora, reforçando a sua visão crítica, contesta: "Tento responder. Talvez, estas mulheres (como eu) tenham percebido que se o ato de ler oferece a apreensão do mundo, o de escrever ultrapassa os limites de uma percepção da vida. Escrever pressupõe um dinamismo próprio do sujeito da escrita, proporcionando-lhe a sua autoinscrição no interior do mundo. E, em se tratando de um ato empreendido por mulheres negras, que historicamente transitam por espaços culturais diferenciados dos lugares ocupados pela cultura das elites, escrever adquire um sentido de insubordinação. Insubordinação que se pode evidenciar, muitas vezes, desde uma escrita que fere 'as normas cultas' da língua, caso exemplar o de Carolina Maria de Jesus, como também pela escolha da matéria narrada."; e, por fim, conclui os seus argumentos de forma contundente: "A nossa escrevivência não pode ser lida como histórias para 'ninar os da casa grande' e sim para incomodá-los em seus sonos injustos".

${ }^{15}$ Aqui entendida a partir da conceituação proposta por Richard Demarcy no livro Semiologia 
do Teatro, organizado por J. Guinsburg et al. (1988). A leitura transversal é aquela em que o espectador não penetra essencialmente na fábula. Ainda que a acompanhe, ela não é seu único objeto de interesse. O que a difere da leitura horizontal consiste na vontade de distinguir as diversas unidades significativas contidas no espetáculo.

${ }^{16}$ Informação extraída de <http://deboraalmeidaportfolio.blogspot.com/2009/08/2003-04candaces-reconstrucao-do-fogo.html $>$.

${ }^{17}$ No campo da produção literária, Allan da Rosa criou o selo de perfil alternativo, Edições Toró, pautado com publicações de um trabalho artesanal e com a presença de autores jovens, vindos da periferia paulistana e sem espaço no mercado editorial. Cf.: <www.edicoestoro.net>.

${ }^{18}$ Parte desta análise integra o Verbete que escrevi sobre o autor intitulado "Allan da Rosa". Para ter acesso ao texto completo, conferir o volume 3 da Antologia Literatura e Afrodescendência no Brasil: antologia crítica (Contemporaneidade), organizada por Eduardo de Assis Duarte (Editora UFMG, 2011). 


\section{Referências}

ALEXANDRE, Marcos Antônio. A cultura negra e seus questionamentos na produção dramatúrgica/espetacular contemporânea. In: DUARTE, Eduardo de Assis; FONSECA, Maria Nazareth Soares (Org.). Literatura e Afrodescendência no Brasil: antologia crítica. Belo Horizonte: Editora UFMG, 2011. Volume 4: história, teoria, polêmica. P. 339-373.

ALEXANDRE, Marcos Antônio. Allan da Rosa. In: DUARTE, Eduardo de Assis; FONSECA, Maria Nazareth Soares (Org.). Literatura e Afrodescendência no Brasil: antologia crítica. Belo Horizonte: Editora UFMG, 2011. Volume 3: Contemporaneidade. P. 519-535.

BANDO de Teatro Olodum; MEIRELLES, Márcio. Cabaré da Rrrrraça. Caderno do Espetáculo, Salvador, 1997/2005.

BIÃO, Armindo Jorge de Carvalho. Artes do Corpo e do Espetáculo: questões de etnocenologia. Salvador: P\&A Editora, 2007.

COMPANHIA dos Comuns. Candaces - A Reconstrução do Fogo. Rio de Janeiro: O Autor, 2003.

EVARISTO, Conceição. Da Grafia-desenho de Minha Mãe, um dos Lugares de nascimento de minha escrita. In: ALEXANDRE, Marcos Antônio (Org.). Representações Performáticas brasileiras: teorias, práticas e suas interfaces. Belo Horizonte: Mazza Edições, 2007. P. 16-21.

EVARISTO, Conceição. Prefácio. In: ROSA, Allan da. Da Cabula. São Paulo: Global, 2008. S. p.

FOUCAULT, Michel. Microfísica do Poder. Organização e tradução de Roberto Machado. 18. ed. Rio de Janeiro: Edições Graal, 2003.

GUINSBURG, Jacob; COELHO NETO, José. Teixeira; CARDOSO, Reni Chaves. Semiologia do teatro. São Paulo: Perspectiva, 1988.

HELIODORA, Bárbara. Bela Apologia da Dignidade da Mulher Negra. O Globo, Rio de Janeiro, 3 abr. 2003. Disponível em: <http://deboraalmeidaportfolio.blogspot.com.br/2009/08/200304-candaces-reconstrucao-do-fogo.html>. Acesso em: 02 ago. 2009.

LOPES, Nei. Enciclopédia Brasileira da Diáspora Africana. São Paulo: Selo Negro, 2004. LOPES, Nei. Apresentação. In: ROSA, Allan da. Da Cabula. São Paulo: Global, 2008. P. 13- 14. MARTINS, Leda Maria. Performance do Tempo Espiralar. In: RAVETTI, Graciela; ARBEX, Márcia (Org.). Performance, Exílio, Fronteiras: errâncias territoriais e textuais. Belo Horizonte: Faculdade de Letras/UFMG, 2002. P. 69-91.

MOTTA, Zezé. Depoimento Concedido apud COMPANHIA dos Comuns. Candaces - A Reconstrução do Fogo. Rio de Janeiro: 2003.

NASCIMENTO, Abdias. Sortilégio II: mistério negro de Zumbi redivivo. Rio de Janeiro: Paz e Terra, 1979.

PAVIS, Patrice. Dicionário de Teatro. Tradução de J. Guinsburg e Maria Lúcia Pereira. São 
Paulo: Perspectiva, 1999.

RICEUR, Paul. La Historia, la Memoria, el Olvido. Buenos Aires: Fondo de Cultura Económica de Argentina, S.A., 2000.

ROSA, Allan da. Da Cabula. São Paulo: Global, 2008.

SOUZA, Ruth de. Depoimento Concedido apud COMPANHIA dos Comuns. Candaces - A Reconstrução do Fogo. Rio de Janeiro: 2003.

VELUMA. Depoimento Concedido apud COMPANHIA dos Comuns. Candaces - A Reconstrução do Fogo. Rio de Janeiro: 2003.

VERGER, Pierre. Lendas Africanas dos Orixás. Tradução de Maria Aparecida da Nóbrega. 4. ed. Salvador: Corrupio, 1997. Ilustrações de Carybé.

VIANNA, Anízio. Performance-Cidadã. In: ALEXANDRE, Marcos Antônio (Org.). Representações Performáticas Brasileiras: teorias, práticas e suas interfaces. Belo Horizonte: Mazza Edições, 2007. P. 139-158.

Marcos Antônio Alexandre é professor de Língua Espanhola e Literaturas Hispânicas da Faculdade de Letras da Universidade Federal de Minas Gerais - UFMG (graduação), de Teoria da Literatura (pós-graduação) e de Teorias do Texto Dramatúrgio e do Texto Espetacular do curso de Teatro da Escola de Belas Artes - EBA-UFMG.

E-mail: marcosxandre@yahoo.com

Recebido em fevereiro de 2012 Aprovado em abril de 2012 